\title{
Clinical Experience with Anticoagulant Therapy during Pregnancy
}

\author{
J. HIRSH, ${ }^{*}$ \ M.D., M.R.A.C.P. ; J. F. CADE, $†$ M.D., M.R.A.C.P.; E. F. O’SULLIVAN, $\ddagger$ M.B.
}

\begin{abstract}
Cummary: Fourteen patients were treated with anti$\checkmark$ coagulants during 15 pregnancies. Eleven had venous thrombosis, three with pulmonary embolism; three had prosthetic heart valves; and one had mitral stenosis with pulmonary hypertension. All 15 were treated with heparin and 10 with warfarin. The mean duration of heparin therapy was 4.5 weeks and of warfarin 14 weeks. There were two minor episodes of recurrent thromboembolism and three minor haemorrhagic episodes during anticoagulant therapy. No fetal or neonatal complications occurred.

There appears to be no ideal anticoagulant regimen for treating thromboembolic disease in pregnancy. A compromise approach based on experimental and clinical findings is suggested, which is considered to offer reasonable protection to the mother without undue risk to the fetus. This is heparin when an anticoagulant is indicated in the first trimester, after 37 weeks' gestation, and for the treatment of the initial thromboembolic episodes. Oral anticoagulants are used at other times when long-term anticoagulant therapy is indicated.
\end{abstract}

\section{Introduction}

Thromboembolic disease has become one of the major causes of maternal mortality in Western communities (Jeffcoate and Tindall, 1965). It is generally accepted that anticoagulant therapy is indicated in the non-pregnant patient for the treatment of venous thrombosis and pulmonary embolism (Barritt and Jordan, 1960; Thomas, 1965; O'Sullivan et al., 1968) and for prophylaxis after heart valve replacement (Duvoisin et al., 1967; Pansegrau et al., 1968). In pregnancy the mortality and morbidity associated with these conditions is probably even higher; however, their treatment with anticoagulant drugs poses a number of unresolved questions.

Of the two available groups of anticoagulants, heparin is thought to be the more effective (O'Sullivan et al., 1968) and is safer for the fetus as it does not cross the placenta (Flessa et al., 1965). Since it must be given parenterally, however, its long-term use is much less convenient than that of the oral anticoagulants. The latter drugs, on the other hand, have been shown to cross the placenta and to predispose to fetal haemorrhage, both experimentally (Quick, 1946; Kraus et al., 1949) and clinically (Quenneville et al., 1959; Finnerty and MacKay, 1962; Johnson and Greenwalt, 1965; Taylor, 1965; Villasanta, 1965a, 1965b; Gilliland, 1966). For this reason their use has generally been considered to be contraindicated dur-

*Second Assistant.

tCardiovascular Registrar.

$\ddagger$ Medical Registrar.

University of Melbourne Department of Medicine, St. Vincent's Hospital, Melbourne, Australia.

SAt present, Associate Professor, Department of Pathology and Medicine, McMaster University, Hamilton, Ontario, Canada. ing pregnancy (Douglas, 1962; Johnson and Greenwalt, 1965; Villasanta, 1965b).

Examination of the available experimental and clinical evidence suggested to us that the incidence of fetal haemorrhage may not be increased unless the mother is given oral anticoagulants near term. An anticoagulant regimen based on this supposition was used in the treatment of 14 patients in 15 pregnancies. The purpose of this paper is to present the results of this series and to discuss the maternal and fetal problems associated with the use of anticoagulant drugs during pregnancy.

\section{Methods}

Coagulation tests were performed on maternal venous and on neonatal mixed cord blood. Whole-blood clotting-times were done by a modification of the Lee-White method. Estimation of prothrombin and kaolin partial thromboplastin times and assays of factors II, V, VII-X complex, VIII, and $\mathrm{X}$ and fibrinogen were performed by methods previously described (Cade et al., 1969).

Anticoagulant Regimen.-The following therapeutic regimen was used: (1) patients with clinically severe or recurrent thromboembolism were treated with heparin for 10 to 14 days and then with an oral anticoagulant (warfarin) until 37 weeks' gestation; (2) patients with clinically minor single episodes of calf vein thrombosis or minor pulmonary embolism were treated for 14 days with heparin only; (3) heparin alone was used after 37 weeks' gestation; and (4) when pregnancy was diagnosed in the first trimester, heparin was used until 13 weeks' gestation and was followed by oral anticoagulants when long-term therapy was indicated. Heparin was administered either by continuous intravenous infusion, and the dose regulated to maintain the whole-blood clotting-time between 20 and 30 minutes at all times or by intermittent 12hourly subcutaneous injection (Calciparine) to produce a clotting-time of 15 to 20 minutes before the next injection. The dose of warfarin was regulated to maintain the onestage prothrombin time at two to two and a half times control levels.

\section{Patients and Results}

Fourteen patients were treated with anticoagulant drugs during 15 pregnancies (see Table). Eleven had venous thrombosis, three of these also had pulmonary embolism; three had prosthetic heart valves; and one had mitral stenosis with pulmonary hypertension.

All 15 cases were given heparin and 10 received warfarin in addition. The mean duration of heparin therapy was 4.5 weeks (range 2 to 6 weeks) and of oral anticoagulant therapy 14 weeks (range 0 to 37 weeks). Two patients developed further thromboembolic complications while being treated 
Patients Treated with Anticoagulants During Pregnancy

\begin{tabular}{|c|c|c|c|c|c|c|}
\hline \multirow[b]{2}{*}{$\begin{array}{l}\text { Case } \\
\text { No. }\end{array}$} & \multirow[b]{2}{*}{ Age } & \multirow{2}{*}{$\begin{array}{c}\text { History } \\
\text { (Times relate to gestation unless otherwise } \\
\text { stated) }\end{array}$} & \multicolumn{2}{|c|}{ Treatment during Pregnancy and Puerperium } & \multicolumn{2}{|c|}{ Comments } \\
\hline & & & Heparin & Warfarin & $\begin{array}{l}\text { Maternal (Clotting-time } \\
\text { at delivery) }\end{array}$ & $\begin{array}{l}\text { Neonatal (Clotting-time } \\
\text { at birth) }\end{array}$ \\
\hline $1^{*}$ & 25 & $\begin{array}{l}\text { Gravida 1, para } O \text {. Chronic rheumatic carditis } \\
\text { with mitral prosthesis } 3 \text { months before } \\
\text { conception }\end{array}$ & $\begin{array}{l}37 \text { weeks' gestation to } 10 \\
\text { days postpartum }\end{array}$ & $\begin{array}{l}\text { Before conception to } 37 \\
\text { weeks' gestation; } \\
\text { postpartum }\end{array}$ & $\begin{array}{l}\text { Small haematoma of } \\
\text { episiotomy }(25 \mathrm{~min} .)\end{array}$ & No complications (4 min.) \\
\hline $2 *$ & 27 & $\begin{array}{l}\text { Gravida 2, para 1. Chronic rheumatic carditis } \\
\text { with mitral prostheses } 2 \text { years before } \\
\text { conception }\end{array}$ & $\begin{array}{l}37 \text { weeks' gestation to } 9 \\
\text { days postpartum }\end{array}$ & $\begin{array}{l}\text { Before conception to } 37 \\
\text { weeks' gestation; } \\
\text { postpartum }\end{array}$ & No complications $(40 \mathrm{~min})$. & No complications (7 min.) \\
\hline 3 & 14 & $\begin{array}{l}\text { Gravida } 1 \text {, para } O \text {. Severe iliofemoral venous } \\
\text { thrombosis at } 28 \text { weeks }\end{array}$ & $\begin{array}{l}28-31 \text { weeks' gestation; } 37 \\
\text { weeks to } 10 \text { days } \\
\text { postpartum }\end{array}$ & $\begin{array}{l}31-37 \text { weeks' gestation; } \\
\text { postpartum }\end{array}$ & $\begin{array}{l}\text { Small haematoma of } \\
\text { episiotomy }(25 \mathrm{~min} .)\end{array}$ & No complications (6 min.) \\
\hline 4 & 25 & $\begin{array}{l}\text { Gravida 1, para } O \text {. Calf and femoral vein } \\
\text { thrombosis at } 20 \text { weeks. Minor pulmonary } \\
\text { embolus before treatment }\end{array}$ & $\begin{array}{l}20-22 \text { weeks' gestation; } 37 \\
\text { weeks to } 7 \text { days postpartum }\end{array}$ & 21-37 weeks' gestation & No complications ( $37 \mathrm{~min})$. & No complications $(6 \mathrm{~min})$. \\
\hline 5 & 23 & $\begin{array}{l}\text { Gravida } 1 \text {, para } \mathrm{O} \text {. Calf vein thrombosis at } 18 \\
\text { weeks }\end{array}$ & $18-20$ weeks' gestation & None & No complications $(-)$ & No complications $(-)$ \\
\hline 6 & 34 & $\begin{array}{l}\text { Gravida } 6 \text {, para } 5 \text {. Aortic prosthesis } 4 \text { years } \\
\text { earlier, anticoagulants not given during this } \\
\text { time, coronary artery embolus at } 34 \text { weeks }\end{array}$ & $\begin{array}{l}34 \text { weeks' gestation to } \\
\text { caesarean section at } 39 \\
\text { weeks; postoperatively for } \\
10 \text { days }\end{array}$ & Postpartum & $\begin{array}{l}\text { Transient hemiparesis } \\
\text { during first } 24 \text { hours of } \\
\text { treatment, despite clotting- } \\
\text { time of } 25 \text { min. }\end{array}$ & No complications $(-)$ \\
\hline 7 & 26 & $\begin{array}{l}\text { Gravida 2, para 1. Past bilateral venous } \\
\text { thrombosis. Major pulmonary embolus at } 12 \\
\text { weeks }\end{array}$ & $\begin{array}{l}12-15 \text { weeks' gestation; } 37 \\
\text { weeks to } 12 \text { days } \\
\text { postpartum }\end{array}$ & $\begin{array}{l}\text { 14-37 weeks' gestation; } \\
\text { postpartum }\end{array}$ & $\begin{array}{l}\text { Threatened abortion at } 16 \\
\text { weeks' gestation, subsided } \\
\text { with bed rest, anticoagu- } \\
\text { lants continued ( } 25 \text { min.) }\end{array}$ & No complications $(4 \mathrm{~min})$. \\
\hline 8 & 30 & $\begin{array}{l}\text { Gravida } 2 \text {, para } 1 \text {. Mitral stenosis with } \\
\text { pulmonary hypertension and severe pulmonary } \\
\text { oedema at } 20 \text { weeks }\end{array}$ & $\begin{array}{l}36 \text { weeks' gestation to } 6 \\
\text { days postpartum }\end{array}$ & $\begin{array}{l}20-36 \text { weeks' gestation; } \\
\text { postpartum until mitral } \\
\text { valvotomy }\end{array}$ & No complications $(-)$ & No complications $(-\rightarrow)$ \\
\hline 9 & 25 & $\begin{array}{l}\text { Gravida } 2 \text {, para } 1 \text {. Iliofemoral venous } \\
\text { thrombosis at } 30 \text { weeks. Immediate } \\
\text { thrombectomy }\end{array}$ & $\begin{array}{l}30-32 \text { weeks' gestation; } 37 \\
\text { weeks to } 7 \text { days postpartum }\end{array}$ & $\begin{array}{l}\text { 31-37 weeks' gestation; } \\
\text { postpartum }\end{array}$ & No complications (40 $\mathrm{min})$. & No complications (10 min.) \\
\hline 10 & 24 & $\begin{array}{l}\text { Gravida } 1 \text {, para } 0 \text {. Recurrent superficial venous } \\
\text { thrombosis. Calf vein thrombosis at } 36 \text { weeks }\end{array}$ & $\begin{array}{l}36 \text { weeks to } 7 \text { days } \\
\text { postpartum }\end{array}$ & & No complications ( $9 \mathrm{~min})$. & No complications (6 min.) \\
\hline 11 & 27 & $\begin{array}{l}\text { Gravida } 1 \text {, para } 0 \text {. Ulcerative colitis for } 12 \\
\text { months. Past iliofemoral venous thrombosis } \\
\text { and pulmonary embolism. Recurrence of } \\
\text { venous thrombosis at } 13 \text { weeks }\end{array}$ & $\begin{array}{l}13-16 \text { weeks' gestation; } 37 \\
\text { weeks to } 7 \text { days postpartum }\end{array}$ & $\begin{array}{l}\text { From before conception } \\
\text { to } 37 \text { weeks' gestation }\end{array}$ & $\begin{array}{l}\text { Premature labour at } 37 \frac{1}{2} \\
\text { weeks'gestation. No } \\
\text { complications }(-)\end{array}$ & No complications $(-)$ \\
\hline 12 & 38 & $\begin{array}{l}\text { Gravida } 1 \text {, para } 0 \text {. Thromboembolic } \\
\text { pulmonary hypertension diagnosed at } 28 \text { weeks }\end{array}$ & $\begin{array}{l}28-30 \text { weeks' gestation; } 36 \\
\text { weeks to } 14 \text { days after } \\
\text { Ceasarean section at } 38 \\
\text { weeks }\end{array}$ & $\begin{array}{l}\text { 29-36 weeks' gestation; } \\
\text { postpartum }\end{array}$ & No complications (-) & No complications (-) \\
\hline 13 & 28 & $\begin{array}{l}\text { Gravida 3, para } 2 . \text { Previous recurrent bilateral } \\
\text { superficial venous thrombosis; calf vein } \\
\text { thrombosis at } 36 \text { weeks }\end{array}$ & $\begin{array}{l}36 \text { weeks' gestation to } 7 \\
\text { days postpartum }\end{array}$ & None & $\begin{array}{l}\text { Atonic uterus with post- } \\
\text { partum haemorrhage } \\
\text { requiring transfusion and } \\
\text { responding to ergometrine } \\
(14 \text { min.) }\end{array}$ & $\begin{array}{l}\text { Twins (1st twin } 7 \text { min., } \\
\text { 2nd twin } 10 \text { min.) }\end{array}$ \\
\hline 14 & 36 & $\begin{array}{l}\text { Gravida } 6 \text {, para } 5 \text {. Severe iliofemoral and calf } \\
\text { vein thrombosis at } 9 \text { weeks }\end{array}$ & $\begin{array}{l}9-13 \text { weeks' gestation; } 37 \\
\text { weeks' gestation to } 7 \text { days } \\
\text { postpartum }\end{array}$ & $\begin{array}{l}\text { From } 13 \text { weeks' } \\
\text { gestation }\end{array}$ & No complications $(-)$ & No complications $(-)$ \\
\hline 15 & 24 & $\begin{array}{l}\text { Gravida } 1 \text {, para } 0 . \text { Calf vein thrombosis at } 32 \\
\text { weeks }\end{array}$ & 32-34 weeks' gestation & None & $\begin{array}{l}\text { Premature labour at } 34 \\
\text { weeks' gestation while still } \\
\text { receiving heparin; no } \\
\text { maternal or retroplacental } \\
\text { haemorrhage }(-)\end{array}$ & $\begin{array}{l}\text { Six weeks premature, } \\
\text { otherwise no complications } \\
(-)\end{array}$ \\
\hline
\end{tabular}

* Same patient.

with anticoagulants. In one (Case 6) an aortic ball-valve prosthesis had been inserted four years previously and no anticoagulants had been used postoperatively. She presented at 34 weeks with a coronary embolus and during the first day of treatment with heparin developed transient symptoms suggestive of a small cerebral embolus. Severe ball variance had occurred with associated valvular incompetence and haemolytic anaemia, and subsequent reoperation was required. The other (Case 11) had a past history of ulcerative colitis and previous venous thrombosis with pulmonary embolism. Despite oral anticoagulant therapy from before conception, she developed a recurrence of venous thrombosis at 13 weeks' gestation and treatment with heparin was required. Two patients (Cases 1 and 3) had minor bleeding complications whi'e being treated with anticoagulants and developed small haematomata of the episiotomy while being treated with heparin. One other patient (Case 13) suffered a postpartum haemorrhage associated with an atonic uterus 18 hours after heparin had been stopped and when her clotting-time was normal, and another patient (Case 7) had a threatened abortion at four months' gestation but delivered a normal infant at term.

In six cases the maternal clotting-time at delivery was significantly prolonged owing to heparin therapy, but in each case the neonatal clotting-time was normal. There were no fetal or neonatal complications.

\section{Discussion}

The problems associated with the use of anticoagulant therapy in pregnancy may be examined by a consideration of the following four questions: (1) Does anticoagulant therapy reduce morbidity and mortality in mothers with venous thromboembolic disease or prosthetic valve replacements, and if so what regimen should be used? (2) Does it predispose to maternal haemorrhage? (3) Does it predispose to fetal haemorrhage? (4) Does it produce fetal damage other than haemorrhage?

\section{Maternal Mortality and Morbidity}

The mortality of antepartum thromboembolism has been reported to be about $15 \%$ in untreated patients, but there has been only one death in over 100 reported cases given anticoagulants (Ullery, 1954; Finnerty and McKay, 1962; DeVita et al., 1965; Villasanta, 1965a). Even allowing for possible selection bias, the available evidence would suggest that anticoagulant therapy significantly reduces mortality in antepartum thromboembolism. The value of long-term anticoagulant therapy in non-pregnant patients with prosthetic heart valves has been well established (Duvoisin et al., 1967; Pansergrau et al., 1968), and it would be expected that the risk of systemic thromboembolism would be at least as great during pregnancy. In the present series of 15 cases (see Table), there were two instances of further thromboembolism during anticoagulant therapy, but both were minor.

\section{Anticoagulant Regimen}

It is difficult to define a regimen of anticoagulant therapy during pregnancy that is safe, practical, and effective, and the approach outlined above is suggested as a reasonable compromise. 
In this series Cases 3, 4, 7, 9, 11, 12, and 14 had severe or recurrent deep venous thrombosis, with or without pulmonary embolism; all were treated with heparin for at least two weeks and then with oral anticoagulants. This approach was taken because we thought that these patients were exposed to both local and general predisposing factors to thromboembolism for the duration of pregnancy (Quenneville et al., 1959; Johnson and Greenwalt, 1965: Gilliland, 1966). In these patients and in those with prosthetic heart valves (Cases 1, 2, and 6) heparin was substituted for warfarin at 37 weeks' gestation in order to avoid exposure of the fetus to oral anticoagulants near delivery should premature labour occur. In fact one patient (Case 11) did come into premature labour only four days after oral anticoagulant therapy was stopped and gave birth to a normal baby without haemorrhagic complications.

Four patients (Cases 5, 10, 13, and 15) had single episodes of calf vein thrombosis and were treated for two weeks with heparin alone. Though it is probable that these patients were also at risk from further thromboembolism, it was decided to observe them closely throughout the remainder of pregnancy. In this group there were no further thromboembolic complications.

Patients already on long-term oral anticoagulant therapy before they became pregnant or who develop thromboembolic complications early in the first trimester (Cases 1, 2, 11, and 14) present a particularly difficult therapeutic problem. Pregnancy was diagnosed early in the first trimester in only one patient (Case 14), and she was given heparin until 13 weeks' gestation when oral anticoagulant therapy was resumed. In the other three (Cases 1, 2, and 11) pregnancy was not diagnosed until late in the first trimester, and the oral anticoagulant which had been given from before conception was continued until 37 weeks' gestation.

The management of patients who are pregnant and who have had previous episodes of venous thromboembolism is uncertain. Those who had had previous single or minor episodes of venous thromboembolism were carefully observed and promptly treated at the first sign of recurrence (Cases 7 , 10 , and 13). On the other hand, it was thought advisable to treat patients who had had previous recurrent deep venous thrombosis or major pulmonary embolism (Cases 11 and 12) with anticoagulants from the time of diagnosis until after delivery.

The place of surgical treatment of venous thromboembolic disease is not clear. Vena caval interruption with or without ovarian vein ligation has been proposed by some (Evans et al., 1968). It is, however, known that this procedure does not always give protection from pulmonary embolism in the nonpregnant patient (Amador et al., 1968; O'Sullivan et al., 1968) and furthermore, that it is associated with some risk to both mother and fetus (Sibthorpe, 1955; DeVita et al., 1965; Taylor, 1965). In the non-pregnant patient vena caval interruption has been thought to be indicated when pulmonary embolism has recurred despite adequate anticoagulant therapy (O'Sullivan et al., 1968). In none of the pregnant patients in the present series was vena caval interruption considered, since there were no episodes of pulmonary embolism during anticoagulant therapy.

Because of the recognized risk of developing thromboembolic complications while taking oral contraceptive drugs (British Medical fournal, 1968; Lancet, 1968; Vessey and Doll, 1968) it is suggested that women who have suffered a thromboembolic episode during pregnancy should avoid the subsequent use of any of these agents.

\section{Maternal Haemorrhage}

Despite the theoretical risks there is no evidence that anticoagulants in therapeutic doses increase the incidence of maternal haemorrhage before, during, or after delivery (Quenneville et al., 1959; Finnerty and MacKay, 1962; Taylor, 1965). On the other hand, the incidence of traumatic bleeding from extrauterine sites such as the episiotomy may be increased. Thus of the seven patients who had prolonged clotting-times at delivery (Cases 1, 2, 3, 4, 6, 7, and 9), two developed small haematomata of the episiotomy (Cases 1 and 3 ). Anticoagulants were not thought to be a contributing factor to bleeding in the other two patients (Cases 7 and 13).

\section{Fetal Haemorrhage}

Oral anticoagulants are generally thought to be contraindicated during pregnancy because of the risk of fetal haemorrhage. This belief is based on both experimental and clinical findings. In animals, Quick (1946) and Kraus et al. (1949) found a very high incidence of fetal haemorrhage and death after giving coumarins to the mother. In both studies large doses were given until term, so that the fetuses were delivered at a time when their coagulation system was severely impaired.

Recent investigations from this department have suggested that the trauma of delivery may be an important contributing factor to fetal haemorrhage when coagulation is impaired by vitamin-K antagonists (Hirsh et al., 1970). In this study all the fetuses of pregnant rabbits given warfarin until term were stillborn with widespread haemorrhage, while there was no fetal haemorrhage when delivery was performed by caesarean section just before term, despite severe depression of coagulation factors in both mother and fetuses. Furthermore, fetal bleeding did not occur when the warfarin was stopped a few days before term, so that the levels of fetal clotting-factors had returned to normal before delivery.

At first sight the reported clinical observations on the use of anticoagulants in pregnancy appear to be contradictory. Villasanta (1965b) reviewed the reported cases of antepartum thrombophlebitis treated with oral anticoagulants and concluded that these drugs should not be used during pregnancy because of the risk of fetal haemorrhage.

Re-evaluation of those case reports in which adequate details were available, however, suggested to us that oral anticoagulants may not increase the risk of fetal damage unless continued until term. Thus among the 10 patients reviewed by Villasanta (1965b) who were still receiving oral anticoagulants at the 40th week of gestation there were five instances of perinatal haemorrhage, of which four were fatal (two fetal and two neonatal). On the other hand, of the 13 fetal deaths in 47 cases given oral anticoagulants at an earlier stage of pregnancy, only one was clearly due to haemorrhage. Furthermore, Runge and Hartert (1954) and Mertz and Breitner (1956) were unable to find evidence of fetal haemorrhage when they gave coumarins to 12 women before they underwent legal abortion.

No fetal or neonatal haemorrhage was encountered in any of the 10 patients in this series who were treated with oral anticoagulants at some time during pregnancy. While the numbers are too small to reach a definite conclusion our findings also suggest that the risk from oral anticoagulants may not be high provided treatment with these drugs is stopped before delivery.

The available evidence, both clinical and experimental, indicates that depression of the vitamin-K-dependent coagulation factors in the fetus due to the placental passage of oral anticoagulant drug is reversible; however, the minimum time required for fetal coagulation factors to return to normal is not known. In Cases 1 and 2, in which oral anticoagulants had been given from before conception until 37 weeks' gestation, neonatal coagulation tests were normal at delivery. On the other hand, even when heparin produced a significant anticoagulant effect in the mother at delivery (Cases 1, 2, 3, 4, 7, and 9) neonatal coagulation was not impaired. 


\section{Other Fetal Damage}

The possibility that oral anticoagulants produce fetal morbidity and mortality by means other than depression of vitamin-K-dependent clotting-factors requires serious consideration. It is possible that the 12 non-haemorrhagic fetal deaths reviewed by Villasanta (1965b) and mentioned above were due to vitamin- $K$ antagonists. Some of the patients, however, had severe pulmonary embolism, and fetal death has also been reported in association with untreated pulmonary embolism (Blum and Barre, 1957). In addition, Runge and Hartert (1954) and Mertz and Breitner (1956) found no evidence of fetal damage in 12 women given coumarins between the second and fifth months of pregnancy before legal abortion. More recently nasal bone malformations have been reported in two cases where the mother was given warfarin in the first two months of pregnancy (Kerber et al., 1968).

Four cases in our series (Nos. 1, 2, 11, and 14) were treated with anticoagulants during the first trimester, three with oral agents and one with heparin, with no evidence of fetal damage. These mumbers, however, are small and certainly do not exclude the possibility that oral anticoagulants can produce effects on the fetus other than depression of coagulation factors. Hence these drugs, and indeed any drugs that cross the placenta, should be given in pregnancy only when there are firm indications. This is particularly so in the first trimester, when the risk of teratogenetic effects is at its greatest. Because of this, our present policy is to instruct women on oral anticoagulant therapy to report at the first possibility of pregnancy. If this is confirmed, treatment with warfarin is stopped and heparin is used until about 13 weeks' gestation.

\section{REFERENCES}

Amador, E., Ting, K. L., and Crane, C. (1968). Fournal of the American Medical Association, 206, 1758.
Barritt, D. W., and Jordan, S. C. (1960). Lancet, 1, 1309.

Blum, M., and Barre, W. (1957). American fournal of Obstetrics and Gynaecology, 73, 440. British Medical fournal, 1968, 2, 187.

Cade, J. F., Hirsh, J., and Martin, M (1969). British Medical fournal, 2, 281 .

DeVita, V. T., Wiener, L., and Massumi, R. (1965). Medical Annals of the District of Columbia, 34, 177

Douglas, A. S. (1962). Anticoagulant Therafy, pp. 248, 312. Oxford, Blackwell Scientific.

Duvoisin, G. E., Brandenburg, R. O., and McGoon, D. C. (1967) Circulation, 35, Suppl. No. 1, p. 70 .

Evans, G. L., Dalen, J. E., and Dexter, L. (1968). Fournal of the American Medical Association, 206, 320.

Finnerty, J. J., and MacKay, B. R. (1962). Obstetrics and Gynecology, 19,

Flessa, H. C., Kapstrom, A. B., Glueck, H. I., and Will, J. J. (1965). American fournal of Obstetrics and Gynecology, 93, 570.

Gilliland, M. J. (1966). Minnesota Medicine, 49, 1597.

Hirsh, J. Cade, J. F., and Gallus, A. (1970). In preparation.

Jeffcoate, T. N. A., and Tindall, V. R. (1965). Australian and New Zealand Fournal of Obstetrics and Gynaecology, $5,119$.

Johnson, S. A., and Greenwalt, T. J. (1965). Coagulation and Transfusion in Clinical Medicine, pp. 116, 157. Boston Little Brown.

Kerber, I. J., Warr, O. S., and Richardson, C. (1968). Fournal of the American Medical Association, 203, 223.

Kraus, A. P., Perlow, S., and Singer, K. (1949). fournal of the American Medical Association, 139, 758.

Lancet, 1968, 1, 962.

Mertz, W. R., and Breitner, J. (1956). Geburtshilfe und Frauenheilkunde, $16,426$.

O'Sullivan, E. F., Hirsh, J., McCarthy, R. A., and de Gruchy, G. C. (1968). Medical fournal of Australia, 2, 153.

Pansegrau, D. G., Rosenfeld, W. C., Calvelo, M. G., Kioschos, J. M., and Kroetz, F. W. (1968). Medical Clinics of North America, 52, 1133. Quenneville, G., Barton, B., McDevitt, E., and Wright, I. S. (1959). American fournal of Obstetrics and Gynecology, 77, 1135.

Quick, A. J. (1946). Fournal of Biological Chemistry, 164, 371.

Runge, H., and Hartert, I. (1954). Gynaecologia, 138, 110.

Sibthorpe, E. M. (1955). British Medical fournal, 2, 1063.

Taylor, J. J. (1965). Postgraduate Medical fournal, 41, 80.

Thomas, D. P. (1965). New England fournal of Medicine, 273, 885.

Ullery, J. C. (1954). American fournal of Obstetrics and Gynecology, 68,

Vessey, M. P., and Doll, R. (1968). British Medical fournal, 2, 199.

Villasanta, U. (1965a). Obstetrics and Gynecology, 26, 534. Villasanta, U. (1965b). American fournal of Obstetrics and Gynecology,
93, 142.

\title{
Effect of Personality on Alveolar Ventilation in Patients with Chronic Airways Obstruction
}

\author{
T. J. H. CLARK, ${ }^{*}$ M.D., B.SC., M.R.C.P.; G. M. COCHRANE, † M.B., B.S., B.sc.
}

S u ummary: A study has been made of the personality of 44 patients with chronic airways obstruction (using the Eysenck Personality Inventory), this being related to the difference between their observed $\mathrm{P} \overline{\mathrm{y}} \mathrm{CO}$ : and that predicted from their F.E.V.l. This was designed to test the hypothesis that those patients with a lower $\mathrm{P}_{\bar{v}} \mathrm{CO}_{2}$ than predicted were the more extravert.

The results showed a significant correlation between extraversion and the departure of $\mathrm{PV}^{\mathrm{CO}} 2$ from predicted Those patients having a lower $\mathrm{P} \bar{v} \mathrm{CO}_{2}$ than predicted were more extravert than those with a $\mathrm{P} \bar{v} \mathrm{CO}_{2}$ higher than predicted. There was no correlation between neuroticism and the $\mathrm{P} \overline{\mathrm{v}} \mathrm{CO}_{2}$.

These results support the hypothesis that the personality of a patient may play an important part in determining the alveolar ventilation found in patients with

*Consultant Physician, Guy's Hospital, London S.E.1

†Lately Medical Student, Guy's Hospital, London S.E.1. chronic airways obstruction. Patients known as "pink puffers" could more appropriately be named "pugnacious pink puffers."

\section{Introduction}

Patients with chronic airways obstruction are known to be liable to develop respiratory failure with $\mathrm{CO}_{2}$ retention, but the factors responsible for $\mathrm{CO}_{2}$ retention are not clear. The mechanical abnormalities associated with airways obstruction play an important part, but there is good evidence that they are not solely responsible for the appearance of $\mathrm{CO}_{2}$ retention. This is witnessed by the poor correlation obtained between the forced expired volume in one second (F.E.V.1) and the $\mathrm{CO}_{2}$ tension $\left(\mathrm{PCO}_{2}\right)$. Burrows et al. (1965) examined this correlation and obtained a regression equation that allows the $\mathrm{PCO}_{2}$ to be predicted from the F.E.V.1-namely,

$$
\text { Mixed venous } \mathrm{PCO}_{2}=\frac{11 \cdot 5}{\text { F.E.V.1 }}+36 \cdot 7
$$

